\section{Proj./Prog./Dept./Div.:}

7 E310

\section{Originator Remarks:}

For original release.

\section{Receiver Remarks:} Waste Tanks Process Control

6. Cog. Engr.:

L. A. Tusler
4. Related EDT No.:

605346

7. Purchase Order No.:

N/A

9. Equip./Component No.:

$N / A$

10. System/Bldg./Facility:

$N / A$

12. Major Assm. Dwg. No.:

$N / A$

13. Permit/Permit Application No.: $N / A$

14. Required Response Date:

$N / A$

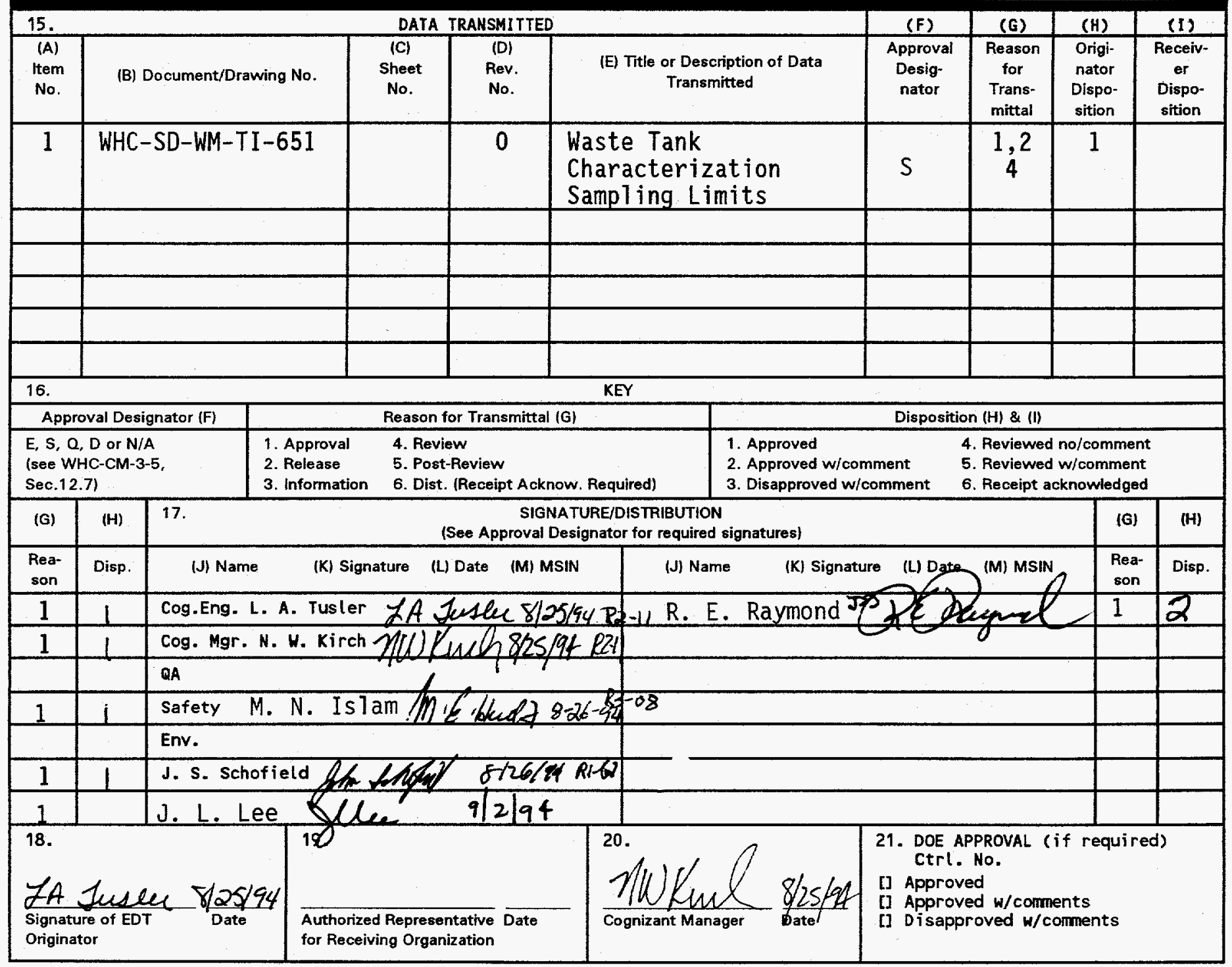




\section{DISCLAIMER}

This report was prepared as an account of work sponsored by an agency of the United States Government. Neither the United States Government nor any agency thereof, nor any of their employees, make any warranty, express or implied, or assumes any legal liability or responsibility for the accuracy, completeness, or usefulness of any information, apparatus, product, or process disclosed, or represents that its use would not infringe privately owned rights. Reference herein to any specific commercial product, process, or service by trade name, trademark, manufacturer, or otherwise does not necessarily constitute or imply its endorsement, recommendation, or favoring by the United States Government or any agency thereof. The views and opinions of authors expressed herein do not necessarily state or reflect those of the United States Government or any agency thereof. 


\section{DISCLAIMER}

Portions of this document may be illegible in electronic image products. Images are produced from the best available original document. 


\section{RELEASE AUTHORIZATION}

Document Number: WHC-SD-WM-TI-651, REV 0

Document Title: WASTE TANK CHARACTERIZATION SAMPLING LIMITS

Release Date: $\quad 9 / 2 / 94$

$* * * * * * * * * * * * *$

This document was reviewed following the procedures described in WHC-CM-3-4 and is:

APPROVED FOR PUBLIC RELEASE

***************

WHC Information Release Administration Specialist:

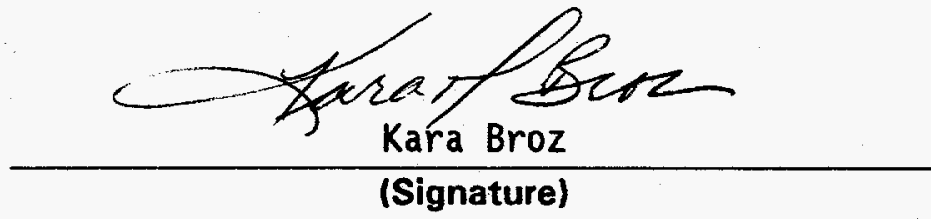




\begin{tabular}{|c|c|c|}
\hline $\begin{array}{l}\text { 2. Title } \\
\text { WASTE TANK CHARACTERIZATION SAMPLING LIMITS }\end{array}$ & $\begin{array}{l}\text { 3. Number } \\
\text { WHC-SD-WM-TI-651 }\end{array}$ & $\begin{array}{c}\text { 4. Rev No. } \\
0 \\
\end{array}$ \\
\hline $\begin{array}{l}\text { 5. Key Hords } \\
\text { Characterization, Double She11 Tanks, Single She11 } \\
\text { Tanks, Aging Waste Tanks, Vapor Sampling, Limits, } \\
\text { Flammable, Ferrocyanide, Organic, Heat Generation, } \\
\text { Criticality, Corrosion } \\
\text { PMB } \% / 2 / 94 .\end{array}$ & $\begin{array}{l}\text { 6. Author } \\
\text { Name: L. A. Tusler } \\
\text { IA JuAle } \\
\text { Organization/Charge code } \\
\text { Waste Tanks Process } \\
\text { 7E310/N4010 }\end{array}$ & Control \\
\hline
\end{tabular}

7. Abstract

This document is a result of the Plant Impementation Team Investigation into delayed reporting of the exotherm in Tank 241-T-111 waste samples. The corrective actions identified are to have immediate notification of appropriate Tank Farm Operations Shift Management if analyses with potential safety impact exceed established levels. This document establishes levels for specified analyses that require notification of the appropriate shift manager.

8. RURPOSE AND USE OF DOCUMENT - This document was prepared fop use within the U.S. Department of Energy and its contractors 1t is to be used aply to perform, direct, or integrate work under U.S. Department ef Energy contracts. This docyment is not approved for public release intil reviewed.

PATENT STATUS - This document cepy, since it is transmitted in advance of patent clearance, is made-ayailable in confidence solely for use in performand of work under contracts with the U.S. Department of Energy. This document is not to be published nor its contents gtherwise disseminated or used for purpeses other than specified bove before patent approval for such release or use has been setured, upon request, from the Patent Counsel, U.S. Department of Energy Field office, Richland, WA.

$\sqrt{ }$ DISCLAIMER - This report was prepared as an account of work sponsored by an agency of the United States Government. Neither the United States Government nor any agency thereof, nor any of their employees, nor any of their contractors, subcontractors or their employees, makes any warranty, express or implied, or assumes any legal liability or responsibility for the accuracy, completeness, or any third party's use or the results of such use of any information, apparatus, product, or process disclosed, or represents that its use would not infringe privately owned rights. Reference herein to any specific commercial product, process, or service by trade name, trademark, manufacturer, or otherwise, does not necessarily constitute or imply its endorsement, recommendation, or favoring by the United States Government or any agency thereof or its contractors or subcontractors. The views and opinions of authors expressed herein do not necessarily state or reflect those of the United States Government or any agency thereof.

9. Impact Level HA S NW $09102 / 94$ 
WHC-SD-WM-TI-651 Rev. 0

\title{
WASTE TANK CHARACTERIZATION SAMPLING LIMITS
}

\author{
Leslie A. Tusler
}

August 25, 1994

WASTE TANKS PROCESS CONTROL

i 
TABLE OF CONTENTS

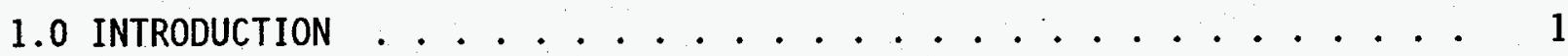

2.0 DOUBLE SHELL TANKS ................. 1

2.1 Tank Composition ................ 1

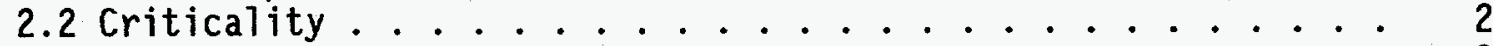

2.3 Organic Material ................ 2

2.4 Heat Generation Rate ................ 2

2.5 Total Fuel Concentration ............. 3

3.0 SINGLE SHELL TANKS ................. 3

3.1 Heat Generation Rate . . . . . . . . . . . . 3

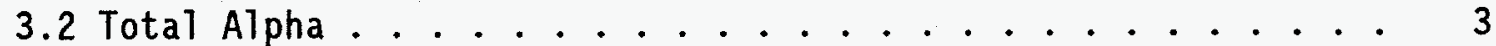

3.3 Ferrocyanide and Potential Ferrocyanide Watch List Tanks . . 4

3.4 Organic and Potential Organic Watch List Tanks ....... 4 3.4 .1 Organic Salts............... 4

3.4 .2 Moisture ................ . . . 4

3.5 Total Fuel Concentration ............. 5

4.0 AGING WASTE TANKS ...................... 5

4.1 Chemical Composition ............... . . 5

4.1 .1 Sodium Concentration ............ 5

4.1 .2 Hydroxide . . . . . . . . . . . . . 5

4.1 .3 Corrosion ............... . . 6

4.2 Heat Generation Rate . . . . . . . . . . . . 6

4.3 Total Fue 1 Concentration ............. 6

5.0 VAPOR SAMPLING ...................... . . 7

5.1 Compounds With Toxicological Properties . . . . . . . 7

5.2 Flammable Gases and Vapors ............. 7

6.0 REFERENCES ........................ 8 
WHC-SD-WM-TI-651 Rev. 0

ACRONYMS

CEA

CES

CPS

DHHS

DQO

DST

IDLH

LFL

NIOSH

OSD

SST

SWP

TFHASP

TOC

TWRS

WHC
Criticality Engineering Analysis

Consensus Exposure Standard

Criticality Prevention Specification

Department of Health and Human Services

Data Quality Objective

Double Shell Tank

Immediately Dangerous to Life and Health

Lower Flammability Limit

National Institute of Occupational Safety and Health

Operating Safety Document

Single Shell Tank

Safe Worker Practice

Tank Farm Health and Safety Plan

Total Organic Carbon

Tank Waste Remediation System

Westinghouse Hanford Company 


\subsection{INTRODUCTION}

This document is a result of the Plant Implementation Team Investigation into delayed reporting of the exotherm in Tank 241-T-111 waste samples. The corrective actions identified are to have immediate notification of appropriate Tank Farm Operations Shift Management if analyses with potential safety impact exceed established levels. A procedure, WHC-IP-0842 Section 12.18, "TWRS Approved Sampling and Data Analysis by Designated Laboratories" (WHC 1994), has been established to require all tank waste sampling (including core, auger and supernate) and tank vapor samples be performed using this document. This document establishes levels for specified analyses that require notification of the appropriate shift manager.

The following categories provide numerical values for analysis that may indicate that a tank is either outside the operating specification or should be evaluated for inclusion on a Watch List. The information given is intended to translate an operating limit such as heat load, expressed in Btu/hour, to an analysis related 1imit, in this case cesium-137 and strontium-90 concentrations. By using the values provided as safety flags, the analytical laboratory personnel can notify a shift manager that a tank is in potential violation of an operating limit or that a tank should be considered for inclusion on a Watch List. The shift manager can then take appropriate interim measures until a final determination is made by engineering personnel.

\subsection{DOUBLE SHELL TANKS}

\subsection{Tank Composition}

$\begin{array}{cc}\text { Variable } & \text { Notification Limit } \\ \mathrm{pH} & \mathrm{pH}_{\mathrm{NO}_{2}^{-}}<12 \\ \mathrm{NO}_{2}^{-}<0.011 \mathrm{M}\end{array}$

The previous variables and their specification limits are taken from the Double-She11 Tank Operating Specifications Document (OSD) (Harris 1992) and the Waste Compatibility Data Quality Objective (DQO) (Carothers 1994). The hydroxide $\left(\mathrm{OH}^{-}\right)$and nitrite $\left(\mathrm{NO}_{2}^{-}\right)$concentrations were generalized to simplify the limits. The hydroxide concentration was converted to a $\mathrm{pH}$ level. The smallest limit values for $\mathrm{NO}_{2}^{-}$were used as the notification limit. Values outside these limits could indicate that the tank is outside the corrosion specification for double shell tanks. Comparison of the analysis results to the OSD will be performed by Waste Tank Plant Engineering. 
WHC-SD-WM-TI-651 Rev. 0

\subsection{Criticality}

$\begin{array}{ll}\text { Variable } & \text { Notification Limit } \\ \begin{array}{l}\text { Maximum Pu density } \\ \text { after in-tank } \\ \text { concentration }\end{array} \\ \begin{array}{l}\text { Solids/Pu mass ratio } \\ \text { (Solids are any non- } \\ \quad \text { fissile material) }\end{array} \\ \text { pH } \quad<1,000 \\ \text { PH }\left(6.2 \times 10^{4} \mu \mathrm{Ci} / \mathrm{L}\right) \text { in solids } \\ \end{array}$

The variables and limits given above are from the Aging Waste OSD (Bergmann 1989), the Tank Safety Screening DQO (Babad 1994) and the DST Criticality Prevention Specification (Vail 1994). The Pu density was converted to $\mu \mathrm{Ci} / \mathrm{L}$ assuming that all $\mathrm{Pu}$ was Pu-239. Exceeding any of the above limits indicates that the tank may be outside the criticality specification for aging waste tanks. Comparison of the results to the OSD will be done by Waste Tank P1ant Engineering.

\subsection{Organic Material}

\section{Variable $\quad$ Notification Limit}

Organic Material Any detectable separate phase organic

The double shell tank organic material limit was taken from the Double Shel1 Tank OSD (Harris 1992). Any detectable separate phase organic in a tank will signify that the tank could be on the Organic Watch List. Evaluation against the watch 1 ist criteria will be performed by Waste Tank Safety Program.

\subsection{Heat Generation Rate}

Variable $\quad$ Notification Limit

For 241-AN, AP \& AW

Maximum heat generation

$$
\begin{aligned}
& 70,000 \mathrm{Btu} / \mathrm{h}\left(>5.74 \times 10^{5} \mu \mathrm{Ci} / \mathrm{L} \mathrm{Cs}-137\right) \\
&\left(>4.04 \times 10^{5} \mu \mathrm{Ci} / \mathrm{L} \mathrm{Sr}-90\right)
\end{aligned}
$$

For 241-SY

$$
\begin{aligned}
& 50,000 \mathrm{Btu} / \mathrm{h}\left(>4.10 \times 10^{5} \mu \mathrm{Ci} / \mathrm{L} \mathrm{Cs}-137\right) \\
& \left(>2.88 \times 10^{5} \mu \mathrm{Ci} / \mathrm{L} \mathrm{Sr}-90\right)
\end{aligned}
$$

The heat generation variables were taken from the Double Shell Tank OSD (Harris 1992). The heat load was translated to Cs-137 and Sr-90 concentrations assuming that the tank holds one million gallons, and $\mathrm{Cs}-137$ and $\mathrm{Sr}-90$ is at 50 percent of the heat load limit. The heat load was then 
WHC-SD-WM-TI-651 Rev. 0

converted to $\mu \mathrm{Ci} / 1$ iter using the Radionuclide Specific Activity and Heat Generation Chart (Wilkins 1984). Exceeding any of the above limits means the tank may surpass the heat load specification for double shell tanks.

Calculation of the actual heat load will be performed by Waste Tank Plant Engineering.

\title{
2.5 Total Fuel Concentration
}

\author{
Variable $\quad$ Notification Limit \\ Total Fuel Conc. $\quad>115 \mathrm{cal} / \mathrm{g}$ \\ (Energetics)
}

The above limit is found in several documents: Ferrocyanide DQO (Buck et a1. 1993), Ferrocyanide Safety Program Safety Criteria for Ferrocyanide Watch List Tanks (Postma et al. 1994), Tank Safety Screening DQO (Babad 1994), Organic DQO (Babad et al. 1994), and the Crust Burn/Flammable Gas DQO (Johnson 1994). Exceeding the total fuel content could put the tank on the ferrocyanide, organic or flammable gas Watch List. Waste Tank Plant Engineering will evaluate the total fuel content and compare the results to the watch list criteria.

\subsection{SINGLE SHELL TANKS}

\subsection{Heat Generation Rate}

$$
\begin{aligned}
& \text { Variable } \\
& \text { Notification Limit } \\
& 40,000 \mathrm{Btu} / \mathrm{h}\left(>3.28 \times 10^{5} \mu \mathrm{Ci} / \mathrm{L} \mathrm{Cs}-137\right) \\
& \text { (> } 2.30 \times 10^{5} \mu \mathrm{Ci} / \mathrm{L} \mathrm{Sr}-90 \text { ) }
\end{aligned}
$$

The limit for heat generation was found in the OSD for Watch List Tanks (Raymond 1994) and the Tank Safety Screening DQO (Babad 1994). The heat load was translated to concentrations of $\mathrm{Cs}-137$ and $\mathrm{Sr}-90$ using the same assumptions that were used for the DST heat generation rates. If the tank is above the 1 imit it could exceed the heat load for single shell tanks. Further calculations will be done by Waste Tank Plant Engineering to determine the actual heat load.

\subsection{Total Alpha}

\section{Variable}

Total Alpha

\section{Notification Limit}

$$
>1 \mathrm{~g} / \mathrm{L}\left(6.2 \times 10^{4} \mu \mathrm{Ci} / \mathrm{L}\right) \text { in solids }
$$

The total alpha safety limit is found in the Tank Safety Screening DQO (Babad 1994). Assuming that all $\mathrm{Pu}$ is $\mathrm{Pu}-239$, the total alpha limit given in the $\mathrm{DQO}$ was converted to $\mu \mathrm{Ci} / \mathrm{L}$ using the Radionuclide Specific Activity and Heat Generation table (Wilkins 1984). A tank that surpasses this limit may 
WHC-SD-WM-TI-651 Rev. 0

have a problem with its criticality specification limits. Waste Tank Plant Engineering will evaluate the values to determine if this is the case.

\subsection{Ferrocyanide and Potential Ferrocyanide Watch List Tanks}

Variable

Total Cyanide (wt\%)
Notification Limit

$>3.9 w t \%$

The ferrocyanide ( $\mathrm{FeCN}$ ) limits were found in Ferrocyanide Safety Program Safety Criteria for FeCN Watch List Tanks (Postma 1994) and the Ferrocyanide DQO (Buck et a1. 1993). If either of these limits is exceeded the tank could be a candidate for the FeCN Watch List. Further analysis will be done by the Waste Tank Safety Program to determine if the tank meets the watch list criteria.

\subsection{Organic and Potential Organic Watch List Tanks}

\subsubsection{Organic Salts}

Variable

Organic Sa7ts
Notification Limit

$\geq 3$ wt\% Total Organic Carbon (TOC)

(equivalent to $10 \mathrm{wt} \%$ sodium acetate)

The organic salts notification limit is from the OSD for Watch List Tanks (Raymond 1994), the Tank Safety Screening DQO (Babad 1993), and the Organic DQO (Babad et al 1994). Exceeding this 1 imit may put the tank on organic watch list. Analyses show that propagating reactions (sodium acetatenitrate/nitrite reactions) could occur with sufficient fuel at elevated temperatures and reduced moisture levels (Babad and Turner, 1993). Further evaluation by the Waste Tank Safety Program will be done to determine if the tank meets the criteria for a watch 1 ist tank.

\subsubsection{Moisture}

$$
\begin{array}{ll}
\text { Variable } & \text { Notification Limit } \\
\% \text { moisture } & <17 \mathrm{wt}^{1}
\end{array}
$$

The notification limit in regards to moisture is found in the Tank Safety Screening DQO (Babad 1994) and the Organic DQO (Babad et a1. 1994). A tank that drops below the limit for moisture could potentially not have water as a mitigating factor against energetic reactions. The Waste Tank Safety Program will determine whether the tank meets the safe, conditionally safe or unsafe criteria (Babad \& Turner, 1993).

\footnotetext{
${ }^{1}$ The limit for percent moisture is in question and is currently being evaluated. The notification
} limit given is to be used only as a flag. 


\subsection{Total Fuel Concentration}

$\begin{array}{ll}\text { Variable } & \text { Notification Limit } \\ \begin{array}{c}\text { Total Fuel Conc. } \\ \text { (Energetics) }\end{array} & >115 \mathrm{cal} / \mathrm{g}\end{array}$

The above limit is found in several documents: Ferrocyanide DQO (Buck et al. 1993), Ferrocyanide Safety Program Safety Criteria for Ferrocyanide Watch List Tanks (Postma et al. 1994), Tank Safety Screening DQO (Babad 1994), Organic DQO (Babad et al. 1994), and the Crust Burn/Flammable Gas DQO (Johnson 1994). Exceeding the total fuel content could put the tank on the ferrocyanide, organic or flammable gas watch list. Evaluation of the total fuel content will be done by Waste Tank Plant Engineering.

\subsection{AGING WASTE TANKS}

\subsection{Chemical Composition}

\subsubsection{Sodium Concentration}

\section{Variable $\quad$ Notification Limit}

Maximum sodium conc.
Tank 101-AZ:
$>5.5 \mathrm{M}$
Other tanks:
$>5.0 \mathrm{M}$

The sodium concentration variables are taken directly from the Aging Waste Tanks OSD (Bergmann 1989). If the maximum sodium concentration is exceeded, high solids precipitation could occur. Waste Tank P7ant Engineering will compare the results to the OSD.

\subsubsection{Hydroxide}

\section{Variable}

[OH]
Notification Limit

$0.01 \underline{M} \leq[\mathrm{OH}] \leq 1.0 \mathrm{M}$

The waste hydroxide concentration was taken from the Aging Waste Tanks OSD (Bergmann 1989). The notification Timit given is to be used only as a flag. The Aging Waste OSD Section 17.4.1.1.3 (Bergmann 1989) should be used for the specific limits. If the limit is exceeded, $\mathrm{Al}(\mathrm{OH})_{3}$ (aluminum hydroxide) could precipitate. Comparison of the analysis results to the OSD will be performed by Waste Tank Plant Engineering. 
WHC-SD-WM-TI-651 Rev. 0

\title{
4.1.3 Corrosion
}

\section{$\underline{\text { Variable }}$}

Waste Nitrite concentration
$\left[\mathrm{NO}_{2}\right]$
Notification Limit

$0.011 \mathrm{M} \leq\left[\mathrm{NO}_{2}\right]$

The waste nitrite concentration limit is from the Aging Waste Tanks OSD (Bergmann 1989). The notification limit given is to be used only as a flag. The Aging Waste OSD Section 17.4.1.1.4 (Bergmann 1989) contains specific limits for the waste nitrite concentrations. If the waste nitrite concentration is below the limit the tank may be outside the corrosion specification for aging waste tanks. Waste Tank Plant Engineering will determine if the analysis is within the OSD Timit.

\subsection{Heat Generation Rate}

\author{
Variable \\ Maximum waste heat \\ content
}

Notification Limit

$$
\begin{aligned}
& 4 \times 10^{6} \mathrm{Btu} / \mathrm{h}\left(>3.28 \times 10^{7} \mu \mathrm{Ci} / \mathrm{L} \mathrm{Cs-137)}\right. \\
& \left(>2.31 \times 10^{7} \mu \mathrm{Ci} / \mathrm{L} \mathrm{Sr}-90\right)
\end{aligned}
$$

The heat generation rate limits were obtained from the Aging Waste Tanks OSD (Bergmann 1989). It was assumed that cesium-137 or strontium-90 is at 50 percent of the heat load limit and the tank volume is one million gallons. Using this information the heat load was converted to $\mu \mathrm{Ci} / \mathrm{L}$ using the Radionuclide Specific Activity and Heat Generation Chart (Wilkins 1984). If the heat load exceeds any of the notification limits, the tank may be above the heat load specification for aging waste tanks. Calculations to determine the actual heat load will be done by Waste Tank Plant Engineering.

\subsection{Total Fuel Concentration}

$\begin{array}{ll}\text { Variable } & \text { Notification Limit } \\ \begin{array}{l}\text { Total Fuel Conc. } \\ \text { (Energetics) }\end{array} & >115 \mathrm{cal} / \mathrm{g}\end{array}$

The above limit is found in several documents: Ferrocyanide DQO (Buck et al. 1993), Ferrocyanide Safety Program Safety Criteria for Ferrocyanide Watch List Tanks (Postma et a1. 1994), Tank Safety Screening DQO (Babad 1994), Organic DQO (Babad et al. 1994), and the Crust Burn/Flammable Gas DQO (Johnson 1994). Exceeding the total fuel content could put the tank on the ferrocyanide, organic or flammable gas watch list. Calculation of the total fuel content will be done by Waste Tank Plant Engineering. 
WHC-SD-WM-TI-651 Rev. 0

\subsection{VAPOR SAMPLING}

\subsection{Compounds With Toxicological Properties}

\author{
Variables \\ Compounds with \\ toxicological \\ properties
}

Notification Limit

$>50 \%$ level designated by

NIOSH as immediately dangerous to life and health (IDLH)

When the shift manager receives a call about a potentially high concentration of a chemical in a tank vapor space, he will compare the data received with the SWP (Safe Worker Practice) that is found in the TFHASP (Tank Farm Health and Safety Plan) (Erickson, 1994). If the shift manager has further questions about the safety of tank farm workers, an industrial hygienist from Waste Tank Safety Support should be contacted to help determine the magnitude of the risk. The IDLH levels for common chemicals can be found in the NIOSH (National Institute of Occupational Safety and Health) Pocket Guide to Chemical Hazards, DHHS (Department of Health and Human Services) Publication Number 90-117. Below is a list of the most common vapors that are most likely to indicate tank concentrations at or above half the IDLH. The complete list is not limited to those below.

\begin{tabular}{lc} 
Vapor & IDLH $(\mathrm{ppm})$ \\
\hline -butanol & 8,000 \\
ammonia & 500 \\
nitric oxide & 100 \\
nitrogen dioxide & 50
\end{tabular}

\subsection{Flammable Gases and Vapors}

Variable Notification Limit

Tank headspace vapors $\geq 20 \%$ of LFL

The above vapor safety limit is from the Watch List OSD (Raymond, 1994). If the LFL limit is surpassed, the tank may be a Flammable Gas or Organic Watch List tank. Waste Tank Safety Program will determine if the tank exceeds the watch 7 ist criteria. 
WHC-SD-WM-TI-651 Rev. 0

\subsection{REFERENCES}

Babad, H., 1994, Tank Safety Screening Data Quality Objective, WHC-SD-WM-004, Westinghouse Hanford Company, Richland, WA.

Babad, H., Blacker, S.M. Redus, K.S., 1994, Data Quality Objective to Support Resolution of the Organic Fue7 Rich Tank Safety Issue, WHC-SD-WM-DQO006, Westinghouse Hanford Company, Richland, WA.

Babad, H. and Turner, D.A., 1993, Interim Criteria for Organic Watch List Tanks at the Hanford Site, WHC-EP-0681, Westinghouse Hanford Company, Richl and, WA.

Bergmann, L.M., 1989, Operating Specifications for Aging-Waste Operations in 241-AY and 241-AZ, OSD- T-151-00017, Rev./Mod. D-0, Westinghouse Hanford Company, Richland, WA.

Boyles, V.C., 1992, Operating Specifications for Single-Shell Waste Storage Tanks, 0SD-T-151-00013, Rev./Mod. D-1, Westinghouse Hanford Company, Richl and, WA.

Buck, J.W., Anderson, C.M., Dulsipher, B.A., et a1., 1993, Ferrocyanide Safety Program: Data Requirements for the Ferrocyanide Safety Issue Developed Through the Data Quality Objectives Process, WHC-EP-0728, Westinghouse Hanford Company, Richland, WA.

Carothers, K.G., 1994, Data Quality Objectives for the Waste Compatibility Program, WHC-SD-WM-DQ0-001, Westinghouse Hanford Company, Richland, WA.

Erickson, A.M., 1994, Tank Farm Hea7th and Safety P7an, WHC-SD-WM-HSP-002, Rev. 1B, Westinghouse Hanford Company, Richland, WA.

Harris, J.P., 1992, Operating Specifications for the 241-AN, AP, AW, AY, AZ and SY Tank Farms, OSD-T-151-0007, Rev./Mod. H-5, Westinghouse Hanford Company, Richland, WA.

Johnson, G.D., 1994, Data Requirements Developed Through the Data Quality Objectives Process for the Curst Burn Issue Associated with Flammable Gas Tanks, WHC-SD-WM-DQ0-003, Westinghouse Hanford Company, Richland, WA.

Osborne, J.W., 1994, Data Quality Objectives for Generic In-Tank Health and Safety Vapor Issue Resolution, WHC-SD-WM-DQO-002, Westinghouse Hanford Company, Richland, WA.

Postma, A.K., et a1., 1994, Ferrocyanide Safety Program Safety Criteria for Ferrocyanide Watch List Tanks, WHC-EP-0691, Westinghouse Hanford Company, Richland, WA. 


\section{WHC-SD-WM-TI-651 Rev. 0 \\ REFERENCES (continued)}

Raymond, R.E., 1994, Operating Specifications for Watch List Tanks, OSD-T-15100030, Rev./Mod. B-0, Westinghouse Hanford Company, Richland, WA.

Vail, T.S., 1994, Draft Waste Storage in Double-Shell Tanks and Associated Equipment, CPS-T-149-00010, Rev. E-0, Westinghouse Hanford Company, Richl and, WA.

WHC, 1994, Waste Tank Project Administration: TWRS Approved Sampling and Data Analysis by Designated Laboratories, WHC-IP-0842 Section 12.18, Westinghouse Hanford Company, Richland, WA.

Wilkins, D.G., 1984, Specific Activity and Heat Generation for Selected Radionuclides, SD-RE-TI-121, Rockwel1 Hanford Operations, Richland, WA. 